Journal of Social and Development Sciences

Vol. 2, No. 1, pp. 5-13, July 2011 (ISSN 2221-1152)

\title{
Stock Returns and Trading Volume Relationship of the Nigerian Banking Sector: An Empirical Assessment
}

\author{
Ugwu, Samuel Chiyeike ${ }^{1}$, *Sule, Kehinde Oluwatoyin², Emerole, Gideon Ahamuefula ${ }^{3}$ \\ ${ }^{1}$ Department of Political Science, Enugu State University of Science and Technology, Nigeria \\ ${ }^{2}$ Department of Banking and Finance, kogi State University, Anyigba, Nigeria \\ ${ }^{3}$ Imaga \& Associates limited, Enugu - Nigeria \\ *kenogidi76@yahoo.com
}

\begin{abstract}
This study assessed the relationship between stock returns and trading volume, using daily data of some Nigerian Banking Sector Stocks. It further checked for both the contemporaneous and causal relationship between stock return and trading volume utilizing data covering ten (10) companies from the Banking Sector. Six hundred and nineteen to seven hundred and six (619-706) observations for a period of thirty - six months (36) from $1^{\text {st }}$ March, 2004 to 28 ${ }^{\text {th }}$ February, 2007, were empirically tested with the Granger-Causality tests. This determined if the Wall Street adage which says, "It takes volume to make prices" was true in the Nigerian Banking Sector. Using the daily data, we first found a negative relation between and absolute value of price changes (return) and price changes itself in the Nigerian Banking Stocks. However, the results from the Granger-Causality test failed to find strong evidence on stock price changes leading volume. This was contrary to evidence reported by study on developed markets but consistent with previous result from the Latin American Market which is an emerging market like that of Nigeria. In fact, in all the ten banks studied, volume seems to lead stock price changes. Thus, we concluded that these set of emerging markets with different institutions and information flows than the developed markets, do not present similar stock/return-volume relationship to the preponderance of studies employed U.S data. The implication of these results was that differences in institutions and information flows in the set of emerging markets are important enough to affect the valuation process of equity securities and warrant further analysis.
\end{abstract}

Keywords: Stock Returns, Trading Volume, Capital Market, Nigerian Banking Sector, Stock Relationship and Stock Price.

\section{Introduction}

The roles of capital market are well articulated through the privatization reform that has seen so many organizations into selling of securities to the general public thus, making the market active in the country. As a result of this, the investors are interested in the price of the stock and the return that will accrue to them in the long run. However, they refuse to take cognizance of the trading volume. Return on stock prices and trading volume are two prime indicators of trading activities in a stock market. These factors are jointly determined by the same market dynamics and may contain valuable information about a security. While the return on stock prices are widely studied for the purpose of forecasting and analyzing information contained in the historical prices, there is little agreement on interpretation on past trading volume.

Therefore, empirical investigations on stock markets traditionally focus primarily on stock prices and their behaviour overtime. Based on the available set of information about a company, its stock price reflects investors' expectations on the future performance of the firm. The arrival of new information causes investors to adapt their expectation and this is the main source for price movements (Mestel et al; 2003). This study is largely inspired by the work of Mishra (2004). Mishra investigated the contemporaneous relation between stock return and trading volume, and checked for a causal relationship between stock return and trading volume in the Indian IT industry. Another important motivator of empirical research of this stock return-volume relation has been the desire to investigate the old street adage which states that "It takes volume to make prices" Though the adage is still questionable but this research will try to answer the above adage in the context of the Nigerian Banking Industry. Thus, what make this attempt interesting is the desire to find out if the stock return-volume relations exhibit different characteristics in an emerging market like 
that of Nigeria vis-à-vis the developed market such as US market. The International Finance Corporation (IFC) listed Nigeria as one of the emerging markets of the world in 1991.

From the foregoing, the purpose of this study was to empirically assess the dynamics between stock-return and trading volume in major banks quoted on the Nigerian Stock Exchange. . Following the introduction is a review of related literature. Section three covers the methodology. Section four is on data presentation and analysis, while section five gives findings, conclusions and recommendations.

\section{Literature Review}

Stock Price and Trade Volume: Market prices are set as the resolution of differences in the valuation assessments of market participants. (In this study, return and prices are used interchangeably). Investors make such assessment based on the analysis of the existing information set about a firm available in the market place. The market information environment is both rich and complex and will consist of information provided by the firm itself and by many other parties (Ryan and Taffler, 2004). Because the investors are sensitive to unexpected information, (especially bad news), they will adjust their position to respond to any new information, making the impact of unexpected trading volume greater than that from expected volume (Chen \& Liao, 2005).

One factor many have not considered in the prediction of prices is the trading. Trading volume is a measure of the quality of shares that changes owners for a given security. Therefore, the amount of daily volume on securities can fluctuate on any given day depending on the amount of new information available about the company, whether options contracts are set to expire soon, whether the trading is full or half day, and among other possible factors. Therefore, it is important to note that volume is a useful tool in determining how disagreement exists with the arrival of new information (Sun, 2003). Of the many different elements affecting trading volume, the one that correlates the most to the fundamental valuation of the securities is the new information provided. This information can be a press release or a regular earnings announcement provided by the company, or it can be third party communication, such as court ruling or release by a regulatory agency pertaining to the company.

Market Information As It Relates To Stock Price and Trading Volume: Information can be referred to as anything that causes investors to act, whether or not it truly has any fundamental impact on the underlying valuation of the company. For example, a University of Michingan study found that, in the absence of clear financial information, investors decisions are swayed by the aesthetics of a company reports (Smith, 2003). It is doubtful that there exists any significant correlation between the aesthetics of a company report and its future earnings, yet the study shows that some individuals attribute value to an organization that produces an aesthetically pleasing report.

However, the link between this information set and changes in stock prices and trading volume activity is a central issue in financial economics. A substantial body of research suggests that the relationship between news and aggregate price and/or trading volume activity is not practically strong. Cutler, Poterba and Summers (1989), Mitchell and Mulherin (1994) provide evidence that stories reported in the financial press have little impact on stock returns and trading volume activity. These results challenge the view that stock price changes are attributable to changes in fundamental values and that share price movements and trading volume activity being driven by sentiment, fads and fashions, noise, momentum or overreaction which Roll (1988) described as occasional frenzy unrelated to concrete information. Notwithstanding the above apparently weak relationship between capital market information flows and price and/or trading volume activity, a substantial literature explores the link between specific news events and corporate prices and trading volume movements. Cutler, Poterba and summer (1989) additionally explore whether the 50 largest one day returns on the standard and poor composite index over a period 1941-1987 are driven by news reports in the Wall Street Journal, but find only a very weak causal relationship.

Prior Studies on Stock Returns and Trading Volume Relationship: An understanding of the relation between stock prices and volume is important for a number of reasons as pointed out by Karpoff (1987). First, the empirical relation between return and volume helps to discriminate between competing theories on 
how information is disseminated in financial market. Second, for event studies that use combinations of return and volume data to infer the combination content of the event in question, the construction of the tests and the validity of the inferences depend on joint distribution of return and volume. Third, the return volume relation is critical in assessing the distribution of returns themselves. For example, the mixture of distributions hypothesis has been employed to view the distribution of price changes (i.e. returns) as a finitevariance mixture of normal distributions where volume is the mixture of variables (Epps and Epps, 1976). Forth, a better understanding of the statistical structure of volume and return can explain technical analysis.

Beyond these rationales, an early and continual motivator of empirical research on the stock return-volume relationship has been a desire to determine whether the Wall Street adage that states that it takes volume to make price is valid. This adage implies that volume causes return. The early empirical research on stock return-volume relationship in financial markets began in the 1960s. Granger and Morgenstern (1963) and Godfrey, Granger and Morgenstern (1964) used weekly data to examine the relation between price changes and volume and find price changes follow a random walk. In the 1970s, Crouch (1970) found a positive correlation between daily volume and absolute values of daily price changes from both market indexes and individual stocks. Examining the relation between volume and returns, Morgan (1976); Epps and Epps (1976); Westerfield (1977); Rogalski (1978) found a positive contemporaneous correlation between volume and price changes for individual stocks by employing daily or monthly data. To explain such results, Epps proposed a theoretical framework consistent with his findings. This framework implies the ratio of volume to returns should be greater for price increase than for price decrease, which was supported by empirical evidence in Smirlock and Starks (1985).

More recent empirical work has investigated the lagged relation between price and volume. For example, Smirlock and Starks (1988), employing individual stock transactions data, document a strong positive lagged relation between volume and absolute price changes. Similarly, using daily data, Bhagat and Bhatia (1996) test for causality in both mean and variance and prove evidence that price changes lead volume, but no evidence that volume lead price changes. In addition, Hiemstra and Jones (1994) find a new result through the use of non-linear Granger - causality. They find a significant positive relation going in both directions between returns and volume.

A number of studies have focused on investigating the stock return-volume in emerging markets Baschi et al., (1996) use weekly data on 29 individual stocks in Turkey and find the price level and volume are co integrated. Saatcioglu and Starks (1988) use monthly data from six Latin American stock markets to test the relation between price changes and volume, finding a positive price-volume relation and a causal relationship from volume to stock price changes but not verse versa. Silvapulle and Choi (1999) use daily Korean Composite Stock Index data to study the linear and non-linear Granger - causality between the two series. Ratner and Leal (2001) examine the Latin American and Asian financial markets and find a positive contemporaneous relation between return and volume in these countries except India. At the same time they observed that there exists a bi-directional causal relation between return and volume.

Although there has been extensive research into the empirical and theoretical aspects of the stock returnvolume relation, this research has focused almost on the well-developed markets, usually the U.S markets. Given the divergent conclusions of this research, further insights should be obtainable through an investigation of an alternative market, in particular an emerging market like Nigeria. The advantages of employing emerging market for this study are several-fold. Because of their generally low correlations with the more developed markets, the emerging markets present a separate data source, so that any data-snooping biases are lessened. In addition, the information flows in emerging markets are not equivalent to the information flows in the more developed markets and there are significant institutional differences across the markets. Information flows and institutions have been previously conjectured to have important implications on the stock return-volume relation based on information flows and the existence of market institutions. Given these hypothesis, an empirical study using alternative market should provide new sight into the relation. In this study, we focused on the Nigerian market that is an emerging market in terms of its low correlations with more developed markets and its information flows that are not equivalent with the information flows in the more developed markets. The most prominent reason for this study is the fact that none of all the studies on the stock return-volume relation sited in the work was done in the Nigerian Capital 
Market, therefore, the need to carry out an empirical study of stock return-volume relation in the Nigerian Capital Market focusing on the banking industry, first for being the most active segment o the market in terms of volume of transactions and second for the strategic position it occupies in the Nigerian economy.

\section{Methodology}

The main aim of this study was to empirically assess the dynamics between stock return and trading volume in major banks listed on the Nigeria stock exchange. Thus, the data set comprised daily data on closing price and trading volume for ten (10) Banks. The daily stock price and volume data for those ten banks for the span of thirty six (36) months obtained from secondary data, from the daily official list of the Nigeria Stock Exchange. The observation for non-trading days (weekend and public holidays) was deleted leaving a number of observations which range from 619 to 706 . The population of this study comprised the entire firm quoted in the Nigerian Stock Exchange in the first and the second tier market. Since the study addressed the stock return volume relations, all firms whose shares had been traded in the floor form part of the population. In the light of foregoing, this study took a sample of firm in the First Tier Security Market, basically the banking sector. Furthermore, a purposive sampling method was employed in this study. The sample was drawn from the banking sub-sector of the Nigerian Stock Exchange. The inclusion in the sample was based on two (2) criteria; first, the sample must include the old and the new generation banks, secondly, the data set over the period of study must be complete. Consequently, after careful examination of data, ten banks are selected to satisfy the criteria above. The banks selected include United Bank for Africa Plc, Union Bank of Nigeria Plc, Wema Bank Plc, First Bank of Nigeria Plc, Guaranty Trust Bank Plc, Access Bank Plc, AfriBank Plc, Unity Bank Plc, Diamond Bank Plc and First Monument Bank Plc. In this study, the researchers employed GrangerCausality test in analysis the relationship existing between stock return and trading volume. The same test has been applied in the work of Mishra (2004), Fan, et al. (2003) and Smirlock and Starks (1988). GrangerCausality tests whether variable X "Granger causes" variable Y. the basic idea according to Pindyck and Rubinfeld (1991), first, X should help to predict Y; that is in a regression of Y against past valves of Y. secondly, $Y$ should not help to predict $X$. The reason is that if $X$ helps to predict $Y$ and $Y$ helps to predict $X$. It is likely that are or more other variables are in fact "causing" the observed changes in both $\mathrm{X}$ and $\mathrm{Y}$.

Models Specification: Going by the above explanations, two alternative forms of models on the stock price changes (return) have been built or designed for the attainment of the overall purpose of this study, which is to test the relationship that exist between stock return and trading volume of the Nigerian Banking Sector.

\section{Model A}

$\mathrm{V}_{\mathrm{t}}=\dot{\alpha}_{0}+\dot{\alpha}_{1} \mathrm{R}_{\mathrm{t}}+\dot{\varepsilon}_{\mathrm{t}}$

$V_{\mathrm{t}}=\beta_{0}+\beta_{1} / \mathrm{R}_{\mathrm{t} /+} \dot{\varepsilon}_{\mathrm{t}}$

Where the dependent variable $V_{t}$ is the log of daily trading volume, the independent variable in equation (1) is the log return and, in equation (2), it's the absolute value of returns and $\dot{\varepsilon}_{\mathrm{t}}$ is a random error term. Stock return will be calculated as the continuously-compounded return using the closing price which is the most commonly used measure of the natural logarithm of return:

$\mathrm{R}_{\mathrm{t}}=\left(\operatorname{Ln}\left(\mathrm{p}_{\mathrm{t}}\right)-\operatorname{Ln}\left(\mathrm{P}_{\mathrm{t}-1}\right)\right.$

Where $\operatorname{Ln}\left(\mathrm{P}_{\mathrm{t}}\right)$ denotes the natural logarithm of the closing price at time t. Model $\mathrm{A}$ is two models in one. This will test the contemporaneous relationship existing between return and trading volume. Since earlier studies of the contemporaneous relation between stock returns and trading volume have established the following three forms of the empirical relationship: a positive relationship between volume and stock returns (Epps, 1975: Rogalski, 1978, a positive relationship between volume and absolute returns (Smirlock and Starks, 1988), and an unrestricted V-shaped relationship between volume and return (Karpoff, 1987, Gallant et al., 1992; Blume et al., 1994). These models will show if the situation is the same in Nigerian contest.

\section{Model B}

After checking the contemporaneous relation between the trading volume and stock return, the dynamics was also examined using the commonly applied tests of Granger-Causality. Here, we tested whether trading volume causes return or return causes trading volume using the following forms models: 
$\mathrm{V}_{\mathrm{t}}=\dot{\varepsilon}_{0}+\sum \dot{\varepsilon}_{\mathrm{t}} \mathrm{R}_{\mathrm{t}}-{ }_{-1}+\sum \partial_{\mathrm{t}}-\mathrm{j}+\dot{\varepsilon}_{\mathrm{it}}$

$\mathrm{R}_{\mathrm{t}}=\mathrm{Y}_{\mathrm{o}}+\sum \hat{\varepsilon}_{\mathrm{t}}^{\mathrm{t}=1} \mathrm{R}_{\mathrm{t}-1}+\sum \beta_{\mathrm{j}} \mathrm{V}_{\mathrm{t}-\mathrm{j}}^{\mathrm{j}=1}+\dot{\varepsilon}_{\mathrm{it}}$ $\mathrm{t}=1$

Where $V_{t}$ is the stock volume traded at time $t, R_{t}$ is the return at time $t$ and $\dot{\varepsilon}_{t}$ is the error term. These models were used to test the hypothesis. We tested for strict Granger-Causality from volume (V) to return (R) a standard joint test (F test) was used to determine whether lagged volume $\left(\mathrm{V}_{\mathrm{t}-\mathrm{j}}\right)$ has significant predictive power for current return $\left(T_{t}\right)$. The null hypothesis that V did not Granger cause $R$ was rejected because the coefficients $\beta_{j}$ for all are jointly significantly different from zero.

\section{Data Presentation and Analysis}

\section{Analysis of Contemporaneous Relation Tests}

The empirical assessment was done around research questions and objective of the study. Table 1 presents the estimated set regression results on the contemporaneous relation for the various banks. The table reports the estimation result for the equations in model A. The result of equation (I) is on the left in the table indicated when signed price change is used as a measure of return while the result of equation (2) is on the right in the table this indicated the estimation with return while the result of equation (2) is on the right in the table this indicated the estimation with absolute return used as a measure of return. The table showed clearly the list of companies, the coefficient and F-Statistics. Also included is the adjusted $\mathrm{R}^{2}$.

Access Bank: The result obtained for Access Bank showed that the estimated equation in log form had a high forecasting performance and goodness of fit. The coefficient of stock returns (-0.0091) exhibited a negative sign resulted in a negative relationship, which means that the higher the returns, the lower the trading volume. Specifically, if returns should increase by one unit, trading volume will fall by 0.0091 units. However, from the value of $\mathrm{R}^{2}$, the coefficient of multiple determinations, it followed that only 28.76 percent of the total variations in trading volume of Access bank was accounted for by the changes in stock returns.

Table 1: Regression Results

\begin{tabular}{|c|c|c|c|c|c|c|c|c|c|c|c|}
\hline \multirow[b]{2}{*}{$\begin{array}{l}\text { QUOTED } \\
\text { BANKS }\end{array}$} & \multirow[b]{2}{*}{ Obs } & \multirow[b]{2}{*}{$\dot{\alpha}_{0}$} & \multicolumn{4}{|c|}{$V_{t}=\dot{\alpha} 0+\alpha \dot{\alpha} 1+R t+E t$} & \multicolumn{4}{|c|}{$\mathrm{Vt}=\boldsymbol{\beta}_{0+\beta 1} / \mathrm{R} / \mathbf{E}_{\mathrm{Et}}$} & \multirow[b]{2}{*}{$\begin{array}{l}\text { R-Bar- } \\
\text { Squared }\end{array}$} \\
\hline & & & $\dot{\alpha}_{1}$ & $\begin{array}{c}\text { F- } \\
\text { Statistics }\end{array}$ & $\begin{array}{c}\text { R- } \\
\text { Square } \\
\text { d }\end{array}$ & $\begin{array}{c}\text { R-Bar- } \\
\text { Squared }\end{array}$ & $\boldsymbol{\beta}_{0}$ & $\beta 1$ & $\begin{array}{c}\text { F- } \\
\text { Statistics }\end{array}$ & $\begin{array}{c}\text { R- } \\
\text { Squared }\end{array}$ & \\
\hline ACCESS BANK & 705 & $\begin{array}{l}13.3129 \\
(64.91)\end{array}$ & $\begin{array}{c}-0.0091 \\
(-0.28)\end{array}$ & $\begin{array}{l}46.6214 \\
{[0.000]}\end{array}$ & 0.2876 & 0.2814 & $\begin{array}{l}13.3318 \\
(64.18)\end{array}$ & $\begin{array}{l}-0.3787 \\
(-0.207)\end{array}$ & $\begin{array}{l}46.6134 \\
{[0.000]}\end{array}$ & 0.2875 & 0.2814 \\
\hline AFRI BANK & 705 & $\begin{array}{l}12.0259 \\
(62.26)\end{array}$ & $\begin{array}{c}-0.0114 \\
(-0.99)\end{array}$ & $\begin{array}{c}50.6559 \\
{[0.000]}\end{array}$ & 0.3391 & 0.3324 & $\begin{array}{l}12.0940 \\
(62.01)\end{array}$ & $\begin{array}{c}-1.5331 \\
(-5.95)\end{array}$ & $\begin{array}{c}57.8192 \\
{[0.000]}\end{array}$ & 0.3694 & 0.3630 \\
\hline FIRST BANK & 704 & $\begin{array}{l}14.3857 \\
(105.41)\end{array}$ & $\begin{array}{l}0.0184 \\
(0.155)\end{array}$ & $\begin{array}{c}54.0658 \\
{[0.000]}\end{array}$ & 0.0542 & 0.3477 & $\begin{array}{l}14.3647 \\
(108.73)\end{array}$ & $\begin{array}{c}-0.2558 \\
(-2.37)\end{array}$ & $\begin{array}{c}55.0062 \\
{[0.000]}\end{array}$ & 0.3578 & 0.3513 \\
\hline $\begin{array}{c}\text { FIRST CITY } \\
\text { MONUMENT } \\
\text { BANK }\end{array}$ & 685 & $\begin{array}{c}12.8726 \\
(30.27)\end{array}$ & $\begin{array}{c}-0.0713 \\
(-2.17)\end{array}$ & $\begin{array}{c}56.6078 \\
{[0.000]}\end{array}$ & 0.4598 & 0.4517 & $\begin{array}{l}12.9516 \\
(30.04)\end{array}$ & $\begin{array}{l}0.0301 \\
(0.10)\end{array}$ & $\begin{array}{c}55.6733 \\
{[0.000]}\end{array}$ & 0.4561 & 0.4479 \\
\hline GTB & 706 & $\begin{array}{l}14.2525 \\
(123.78)\end{array}$ & $\begin{array}{c}-0.0101 \\
(-0.66)\end{array}$ & $\begin{array}{c}21.4924 \\
{[0.000]}\end{array}$ & 0.2386 & 0.2275 & $\begin{array}{l}14.1768 \\
(121.86)\end{array}$ & $\begin{array}{l}0.6552 \\
(1.41)\end{array}$ & $\begin{array}{l}12.2697 \\
{[0.000]}\end{array}$ & 0.1518 & 0.1395 \\
\hline UNITY BANK & 698 & $\begin{array}{l}11.7056 \\
(31.71)\end{array}$ & $\begin{array}{c}-0.1629 \\
0-3.45\end{array}$ & $\begin{array}{c}53.1453 \\
{[0.000]}\end{array}$ & 0.4394 & 0.4312 & $\begin{array}{l}11.8541 \\
(28.80)\end{array}$ & $\begin{array}{c}-0.3647 \\
(-0.30)\end{array}$ & $\begin{array}{c}51.1636 \\
{[0.000]}\end{array}$ & 0.4301 & 0.4217 \\
\hline $\begin{array}{l}\text { DIAMOND } \\
\text { BANK }\end{array}$ & 619 & $\begin{array}{l}11.2876 \\
(41.48)\end{array}$ & $\begin{array}{c}-0.2007 \\
0-3.70\end{array}$ & $\begin{array}{l}21.8429 \\
{[0.000]}\end{array}$ & 0.2672 & 0.2550 & $\begin{array}{c}11.3330 \\
(41.30)\end{array}$ & $\begin{array}{l}6.6121 \\
(2.44)\end{array}$ & $\begin{array}{c}20.8268 \\
{[0.000]}\end{array}$ & 0.2580 & 0.2456 \\
\hline UBA GROUP & 704 & $\begin{array}{c}13.9961 \\
(58.57)\end{array}$ & $\begin{array}{c}-0.0166 \\
(-0.66)\end{array}$ & $\begin{array}{c}29.1762 \\
{[0.000]}\end{array}$ & 0.2990 & 0.2888 & 14.1054 & -1.3283 & $\begin{array}{c}35.0326 \\
{[0.000]}\end{array}$ & 0.3387 & 0.3290 \\
\hline UNION BANK & 704 & $\begin{array}{l}14.2683 \\
(131.65)\end{array}$ & $\begin{array}{c}-0.0245 \\
(-1.88)\end{array}$ & $\begin{array}{l}21.9647 \\
{[0.000]}\end{array}$ & 0.2431 & 0.2320 & $\begin{array}{l}14.3089 \\
(134.15)\end{array}$ & $\begin{array}{l}0.1025 \\
(0.39)\end{array}$ & $\begin{array}{c}21.5241 \\
{[0.000]}\end{array}$ & 0.2394 & 0.2282 \\
\hline WEMA BANK & 705 & $\begin{array}{c}12.4290 \\
020.39 \\
\end{array}$ & $\begin{array}{c}-0.0580 \\
(-1.92)\end{array}$ & $\begin{array}{c}72.0027 \\
{[0.000]}\end{array}$ & 0.5125 & 0.5053 & $\begin{array}{c}12.4742 \\
(19.25)\end{array}$ & $\begin{array}{c}-0.5626 \\
(-0.48)\end{array}$ & $\begin{array}{c}71.2996 \\
{[0.000]}\end{array}$ & 0.5100 & 0.5029 \\
\hline
\end{tabular}


Afri Bank: Results obtained for AfriBank Plc revealed empirical evidence which suggested a negative correlation between stock returns and trading volume. The log specification showed that a negative coefficient of $(-0.0114)$ was estimated for stock returns which indicated that the higher the returns, the lower the trading volume in Afri bank.

First Bank: For First Bank Plc, the log result obtained for the F-statistic was 54.0658 was highly significant at 1 percent and 5 percent levels of significance. This implied that a strong positive correlation existed between trading volume and stock returns. Although, the estimated volume equation was capable of predicting about 35.42 percent of the systematic variations in trading volume in the First Bank as provided by stock returns. Thus, with a coefficient of $(0.0184)$, it then implied that a 10 percent increase in stock returns will in no time result to increase of 0.184 percent in the trading volume of First Bank.

First City Monument Bank Plc: The results obtained for FCMB as regards the "Log" equation showed a negative correlation between the volume of stock traded and stock price returns. This was because the coefficient is -0.0713 and the F-statistic of 56.65078 were significant and different from zero at 1 percent level of significance. The coefficient of stock price was also significant and different from zero at the 1 percent level of significance. The coefficient of stock price was significant at the $1 / 2$ percent level of significance since the observed T-value of (-2.7) exceeded the critical T-value of 2.210 .

Guaranty Trust Bank Plc: For Guaranty Trust Bank plc, the log equation results obtained confirmed that changes in stock returns provoked the volume of stock traded in the bank's stock but such a provocation took place in an amative manner. Thus the higher the stock returns, the lower the volume A 10 percent rise in stock returns will generate 0.101 percent decline in the trading volume. How ever, only 23.86 percent of changes in trading volume were explained by stock nice changes. In the absolute equation of return a positive relationship was obtained between volume of stock and stock price.

Unity Bank Plc: On the part of Unity Bank Plc, the estimated results was obviously showing a negative correlation between stock return and trading volume with the -0.1629 coefficient of stock return which was, significantly a different from zero, it follows that changes in stock prices goes a log way in engendering a decline in the trading volume of the bank. Stock prices and traded stock does have a negative relationship.

Diamond Bank Plc: The results obtained with the "Log" equation of Diamond Bank Plc confirmed a negative correlation between volumes of stocks traded and stock prices. A critical evaluation of the estimated equation reveals that 10 percent increase in stock prices brought about 2.007 percent reductions in trading volume. The coefficient of returns (prices) is statistically different from zero even at 1 percent level of significance. The implication here was that stock prices impacted significantly and negatively in the determination of traded stocks. The over all equation was significant as shown by an F-value of 21.8429 .

United bank for Africa plc: The case of United Bank for Africa (UBA) Plc and the results obtained showed a negative correlation between returns and trading volume with a slope coefficient of $(-0.0166)$ for the returns, it thus implied that a negative relationship exist between the aforementioned variables.

Union Bank Nigeria Plc: Results obtained from Union Bank Plc showed a very high and good fit of the regression equations. In the "log specification, the goodness of fit of the model was achieved on the statistical significance of the F-ratio which stood of at 21.9674, this was because the calculated F-ratio 21.9674 exceeds the table F-value of 3.90 at the 1 percent level it thus, justify apparently that, the higher the prices of stocks in the market, the lower the volume of stocks traded in the market.

\section{Analysis of Causality Test Result and Findings}

After checking for the contemporaneous relation between the trading volume and stock returns, the dynamics was examined, using the commonly applied tests of Granger causality which has been used in previous research on developed markets to test whether volume leads return or return leads volume. Granger causality tests whether variable X "Granger causes" variable Y, that is, whether $\mathrm{x}$ leads $\mathrm{Y}$ after controlling for past values of $Y$. In this case, we tested whether returns leads volume or volume leads returns, 
but we need to control for any serial correlation in the dependent variable itself. Granger causality test is in effect in F-test for block exogeneity, and as such is vulnerable to serial correlation. Therefore, before running the Granger causality test, we corrected the data series for first order auto correlation.

Table 2: Casualty Test Result

\begin{tabular}{|c|c|c|c|c|c|c|c|c|c|c|}
\hline $\begin{array}{l}\text { Quoted } \\
\text { Banks }\end{array}$ & \begin{tabular}{|l|} 
Access \\
Bank \\
\end{tabular} & \begin{tabular}{|l|} 
AFRI \\
Bank
\end{tabular} & \begin{tabular}{|l|l|} 
First \\
Bank
\end{tabular} & FCMB & Gtb & \begin{tabular}{|l|l|} 
Bank \\
Unity
\end{tabular} & $\begin{array}{l}\text { Diamond } \\
\text { Bank }\end{array}$ & UBA & $\begin{array}{l}\text { Union } \\
\text { Bank }\end{array}$ & $\begin{array}{l}\text { WEMA } \\
\text { Bank }\end{array}$ \\
\hline \multicolumn{11}{|c|}{ Test of Casualty from Return to Volume $\lambda_{1}=0$ in $V t=\lambda_{0+\Sigma} \lambda_{t-1+\Sigma} R_{j} V_{t-j+} \epsilon_{1 t}$} \\
\hline \multirow[t]{2}{*}{ F-Statistics } & 11.5132 & 0.2984 & 0.0085 & 0.5433 & 13.1941 & 20.7107 & 1.7157 & 0.0278 & 3.9791 & 4.5386 \\
\hline & {$[0.000]$} & {$[0.742]$} & [0.992] & {$[0.581]$} & {$[0.000]$} & {$[0.000]$} & {$[0.181]$} & {$[0.973]$} & {$[0.079]$} & {$[0.011]$} \\
\hline R-Squared & 0.0318 & $0.8493^{\mathrm{E}-3}$ & $0.2414^{\mathrm{E}-4}$ & 0.0016 & 0.0362 & 0.5625 & 0.0055 & $0.00079^{\mathrm{E}-2}$ & 0.0112 & 0.0127 \\
\hline \multicolumn{11}{|l|}{ SQUARED } \\
\hline \multicolumn{11}{|c|}{ Test of Casualty from Volume to Return $\beta_{j==0}$ in $R t=\gamma_{0+\Sigma} \gamma_{1} R_{t-1+\Sigma} \beta_{j} V_{t-j+} \epsilon_{2 t}$} \\
\hline \multirow[t]{2}{*}{ F-Statistics } & 7.3422 & 4.3074 & 41.1003 & 65.7609 & 71.9506 & 22.8624 & 4.5888 & 28.6482 & 28.9205 & 12.1285 \\
\hline & {$[0.001]$} & {$[0.014]$} & {$[0.000]$} & {$[0.000]$} & {$[0.000]$} & {$[0.000]$} & {$[0.001]$} & {$[0.000]$} & {$[0.000]$} & {$[0.000]$} \\
\hline R-Squared & 0.0205 & 0.0121 & 0.1048 & 0.1617 & 0.1701 & 0.0617 & 0.0147 & 0.0756 & 0.3178 & 0.334 \\
\hline R-Bar & 0.0177 & 0.0093 & 0.1023 & 0.1592 & 0.1678 & 0.0590 & 0.0115 & 0.0729 & 0.3068 & 0.0306 \\
\hline \multicolumn{11}{|l|}{ Squared } \\
\hline \multicolumn{11}{|c|}{$\begin{array}{l}\text { Test of Casualty from Absolute Returns to Volume } \lambda_{i==0} \text { in } V t=\lambda_{0}+\Sigma \lambda_{i} \\
\end{array}$} \\
\hline \multirow[t]{2}{*}{ F-Statistics } & 11.5132 & 0.0398 & 0.0498 & 0.5974 & 13.4455 & 28.3477 & 6.3502 & 0.0280 & 4.0107 & 5.5481 \\
\hline & {$[0.000]$} & {$[0.961]$} & {$[0.951]$} & {$[0.550]$} & {$[0.000]$} & {$[0.000]$} & {$[0.002]$} & [0.973] & [0.019] & {$[0.004]$} \\
\hline R-Squared & 0.0318 & $0.1136^{\mathrm{E}-3}$ & $0.1422^{\mathrm{E}-3}$ & 0.0017 & 0.0369 & 0.0755 & 0.0202 & $0.7990^{\mathrm{E}-4}$ & 0.0113 & 0.0156 \\
\hline R-Bar - & 0.0290 & -0.0027 & -0.0027 & -0.0012 & 0.0341 & 0.0729 & 0.0170 & -0.0028 & 0.0085 & 0.0128 \\
\hline \multicolumn{11}{|l|}{ Squared } \\
\hline \multicolumn{11}{|c|}{ Test of Casualty From Volume to Absolute Returns $\beta_{\mathrm{j}}=0$ in } \\
\hline \multirow[t]{2}{*}{ F-Statistics } & 19.3206 & 4.3156 & 49.5680 & 152.4804 & 84.7827 & 100.7234 & 2.5724 & 35.4175 & 119.9582 & 104.4204 \\
\hline & {$[0.000]$} & {$[0.001]$} & {$[0.000]$} & {$[0.000]$} & {$[0.000]$} & {$[0.000]$} & {$[0.077]$} & {$[0.000]$} & {$[0.000]$} & {$[0.000]$} \\
\hline R-Squared & 0.2372 & 0.0122 & 0.01239 & 0.3039 & 0.1943 & 0.2250 & 0.0083 & 0.0919 & 0.2553 & 0.2295 \\
\hline R-Bar- & 0.0050 & 0.0093 & 0.1214 & 0.3073 & 0.1920 & 0.0007 & 0.0052 & 0.0893 & 0.2531 & 0.2273 \\
\hline Squared & & & & & & & & & & \\
\hline
\end{tabular}

Tables 1 and 2 present the results for equations. In the test of the null hypothesis that changes in stock price did not result in changes in trading volume, the F-statistics was significant at 5 percent level for three of the banks while the other seven banks F-statistics is insignificant. Therefore, we find some evidence supporting trading volume causing returns, yet for most banks stock trading volume those not lead returns. In addition, all adjusted $\mathrm{R}^{2}$ values are very low, which indicated that there was little explanatory power for future returns predicted that publicly available information (that is past trading volume and past return). In the null hypothesis that trading volume those did not result in changes in price, the F-statistics was significant at 1 percent level in all cases that is for the ten banks, thus we rejected the null hypothesis and find strong evidence for trading volume causing stock return. Moreover, in all cases the higher volume is adjusted R2 indicates that there was a higher explanatory power that a large proportion of movement of trading volume can be predicted by past return and past trading volume. Inspection of individual coefficient (not reported) showed that much of extra explanatory power comes from past volume terms indicating that volume had strong auto regressive properties.

Thus, for the Nigerian Banking Sector in general, we find evidence supporting volume "causing" returns. The results of our Granger causality tests are not consistent with previous evidence from the U.S. markets which have mostly shown that returns "cause" volume but not vice versa. These results for Nigerian banking sector imply the opposite, volume "causing" returns with causality not running in the other direction this was consistent with the results from the Latin American markets. The first models were used to check if there is any relationship between stock return and trading volume in the stocks of the Nigerian Banking sector. The result showed that the volume of stocks traded has an inverse relationship (that is a negative relationship) with stock return or prices. This the higher the stock prices, the lower the trading activities which 
nevertheless conform to the theoretical expectations, that the higher the price, the lower the quantity demanded of a product.

From the foregoing,, we found out that there is a relationship between trading volume and stock return, we therefore went further to empirically test the type of relationship to further buttress our objective consistent with previous evidence from the US, India and China market (Mishra, 2004). Fan et al (2003) which have mostly shown that returns "cause" volume but vice versa. The results for the Nigerian Capital Market imply the opposite, volume "causing" returns with causality not running in the other direction. This consistent with result from Latin American Market is the work of Saateioglu and Starks, (1998). This study has therefore shown and points to the direction of continued improvement of the Nigerian Capital Market in terms of informational efficiency so as to increase the fund mobilization effort of the Nigerian capital Market for national development.

\section{Concluding Remarks}

This study assessed the relationship between stock returns and trading volume as the Nigeria Banking stock. The main motivation was derived from the Wall Street adage which states that it takes volume to make price. An attempt has also been made to utilize the regression techniques to assess this relationship. However, a number of studies had focused on well developed market in respect to return-volume relations Baschi, et. al. (1996) Saatcioglu and Starks (1998) and found out that price level and volume are co-integrated and that a casual relationship from volume to stock price changes depending on the type of market. This study expands the line of enquiry into the Nigerian Capital Market in pursuance of this, daily stock price and volume data for a period of thirty-six months was collected for ten individual banks which includes old and the new generation banks in Nigeria. In addition, two models were specified and estimated.

However, the results of this study have shown that there is a negative relationship and that it takes volume to make price in the Nigerian Capital Market Several factors have been identified as reasons for the difference in our result compared to the more developed market. In order to improve on the quality of the Nigerian Capital Market as regards stocks return and trading volume, the following recommendations are proposed: The buyand-hold attitude of investors with regards to securities impairs activities on the stock exchange market. It is recommended that investors should be encouraged to invest for speculative purposes. This requires a sociocultural re-orientation by the stock exchange .The present Stock Exchange should review the full listing requirements in order to make them less stringent so as to be able to absorb small and medium sized companies Efforts should be made to over haul the necessary laws and regulation to instill more efficiency in the handling of securities and transactions by the Registrars and stock brokers as transactions often take weeks or months to be finalized. The Stock Exchange must ensure that all hands on deck to work out a new strategy to shorten the duration of raising funds in the market as the length of period long and discouraging. There should the adequate mobilization of savings from numerous economic units for economic growth and development if the stock return-volume relation is to remain positive. In addition, the provision of sufficient liquidity for any investor or group of investors is necessary for increase in volume of trading. Again, Government should work out modalities to increase transparency in the markets in terms of dealings, and also enforce policies that will deepen the market by the type of securities traded, so that Nigerians will invest more in shares. Investors and financial analysis must carefully look at volume variables in determining their investment strategies, because it has been note that investors are interested in the price of stock and the return that will accrue to them in the long run but however, refused to take cognizance of the trading volume.

\section{References}

Baschi, E., Suheyla, O., \& Kursat, A., (1996). A Note on Price-Volume Dynamics in an Emerging Stock Market. Journal of Banking and Finance, 20, 389-400.

Berry, T. D., \& Howe, K. M., (1994). Public Information Arrival, Journal of Finance, 49(4), 1331-1346.

Bhagat, S., \& Bhatia, S., (1996). Trading Volume and Price Variability: Evidence on Lead-Lag Relation from Granger-Causality Tests. Working paper, University of Colorado at Boulder.

Buiter, W. H. (1984). Granger-Causality and Policy Effectiveness. Economica, New Series, 51, 151-162. 
Blume, L., Easley, D., \& O' Hara, M. (1994). Market Statistics and Technical Analysis: The Role of Volume. Journal of Finance, 49(1), 153-181.

Chen, H., \& Liao, C. C. (2005). Agent-Based Computational Modeling of the Stock Price-Volume Relation. Information Science, 170, 75-100.

Crouch, R. L. (1970). The Volume of Transactions and Price Changes on the New York Stock Exchange. Financial Analyst Journal, 26, 104-109.

Cutler, D. M., Poterba, J. M., \& Summer L. H. (1989). What Drives Stock Price. Journal of Portfolio Management, 15(3), 4-12.

Epps, T. W., \& Epps, M. I. (1976). The Stochastic Dependence of Security Price Changes and Transaction Volumes: Implications for the Mixtures-of-distributions Hypothesis. Econometrica, 44, 305-321.

Gallant, A. R., Rossi, P. E., \& Tauchen, G. (1992). Stock Price and Volume. Review of Financial Studies, 5(2), 199242.

Fan, X., Groenewold, N., \& Wu, Y., (2003). The Stock Return- Volume Relation and Policy Effects: A Case of the Chinese Energy Sector. A discussion paper 03-15 of the University of Western Australia, Presented at the $1^{\text {th }}$ Annual Conference of the Association for Chinese Economics Studies on the $2^{\text {nd }}-3^{\text {rd }}$ October.

Godfrey, M. D., Granger, C. W. J., \& Morgenstern, O. (1964). The Random -Walk Hypothesis of Stock Market Behavior. Kyklos, 17(1), 1-30.

Granger C. W. J., \& Morgenstern, O., (1963). Spectral Analysis of New York Stock Market Prices. Kyklos, 16(1), $1-27$.

Hiemstra, C., \& Jones, J. D. (1994). Testing for Linear and Non- Linear Granger -Causality in the Stock Price Volumes Relation. Journal of Finance, 49(5), 1639-1664.

Karpoff, J. M., (1987). The Relation between Price Changes and Trading Volume: A Survey. Journal of Financial and Quantitative Analysis, 22, 109-126.

Mitchell, M. L., \& Mulherin, J. H., (1994). The Impact of public Information the Stock Market. Journal of Finance, 1, 541- 566.

Mestel, R., Gurgul, H., \& Majdosz, P., (2003). The Empirical Relationship between Stock Returns, Return Volatility and Trading Volume in the Austrian Stock Market. University of Graz, Institute of Banking and Finance, Research Paper.

Mishra, V., (2004). The Stock Return-Volume Relation: Evidences From Indian IT Industry. Retrieved October 22, 2008 from http://papers.ssrn.com/sol3/paper.cfm.

Morgan, I. G., (1976). Stock Price and Heteroscedasticity. Journal of Business, 49, 496-508.

Pindyck, R. S., \& Rubinfeld, D. L., (1991). Econometric Models and Economic Forecasts, McGraw- Hill Inc., New York.

Ratner, M., \& Leal, R. P. C., (2001). Stock Returns and Trading Volume: Evidence from the Emerging Markets of Latin America and Asia. Journal of Emerging Markets, 6(1), 5-22.

Rogalski, R. J. (1978). The Dependence of Prices and Volume. Review of Economics and Statistics, 8, 268-274.

Roll, R., (1988). R2. Journal of Finance, 43(2), 541-566.

Ryan, P., \& Traffler, R. J. (2004). Are Economically Significant Stock Returns and Trading Volumes Driven by Firm- Specific News Releases? Journal of Business Finance and Accounting, 31(1\&2), 49-82.

Saateioglu, K., \& Starks, L. T. (1998). The Stock Price-Volume Relationship in Emerging Stock Markets: The Case of Latin America. International Journal of Forecasting, 14, 215-225

Silvapulle, P., \& Choi, J. S., (1999). Testing for linear and Non-linear Granger-Causality in the stock pricevolume relation: Korean Evidence. Quarterly Review of Economics and Finance, 39, 59-76.

Smirlock, M., \& Starks L. T., (1985). A further Examination of Stock Price Changes and Transaction Volume. Journal of Financial Research, 8, 217-225.

Smirlock, M., \& Starks L. T. (1988). An Empirical Analysis of the Stock Price-Volume Relationship. Journal of Banking and Finance, 12(1), 31-41.

Smith, S. D., (2003). The Ticker. Money Magazine, 1, 22.

Sun, W., (2003). Relationship between Trading Volume and Security Price and Return. Retrieved on June 21, 2008 from http://ssg.mit.edu/group/waltsun/docs/Area.ExamTR2638.pdf.

Westerfield, R., (1977). The Distribution of Common Stock Price Changes: An Application of Transactions Time and Subordinate Stochastic Models. Journal of Finance and Quantitative Analysis, 12, 743-765. 